\title{
CELL DIVISION KINETICS AND DNA SYNTHESIS IN THE IMMATURE SERTOLI CELLS OF THE RAT TESTIS
}

\author{
F. NAGY* \\ Department of Anatomy, State University of New York, \\ Upstate Medical Center, Syracuse, New York, U.S.A.
}

(Received 18th March 1971, accepted 12th May 1971)

\begin{abstract}
Summary. Using $\left[{ }^{3} \mathrm{H}\right]$ thymidine and autoradiography, the kinetics of cell division were studied in the immature Sertoli cells of the newborn rat testis. The average durations of the cell cycle and its components were: generation time, $16.4 \mathrm{hr}$; DNA synthesis, $10.1 \mathrm{hr}$; mitosis, $0.75 \mathrm{hr}$; $\mathrm{G}_{2}$ plus prophase, $3 \cdot 6 \mathrm{hr}$.

It was also shown that the mitotic activity of the immature Sertoli cells continues until 2 weeks after birth, whereas a decreasing percentage of these cells continues to incorporate $\left[{ }^{3} \mathrm{H}\right]$ thymidine until the 7 th postnatal week. Mitotic and labelling patterns determined at various stages in the maturation of the Sertoli cells were correlated with events in the seminiferous epithelium.
\end{abstract}

\section{INTRODUCTION}

Investigations of the mammalian testis are abundantly recorded in the literature. The majority of these reports are concerned with the germinal and interstitial cells while relatively little is known of the mature Sertoli cell, and even less is known of the immature form, the supporting cell. Studies of the latter have dealt primarily with its development (Sapsford, 1962, 1963; Flickinger, 1967) and its morphology (Clermont \& Perey, 1957; Gardner \& Holyoke, 1964).

While mature Sertoli cells do not appear to undergo any mitotic activity (Clegg, 1963), the immature form of the cell is quite capable of mitotic division. Glermont \& Perey (1957) reported that multiplication of these cells occurs in fetal and neonatal rat testes and continues until 12 to 15 days after birth. The present investigation was aimed at providing information about the cell division kinetics of newborn rat supporting cells using tritiated thymidine and high resolution autoradiography. In addition, the mitotic events and the DNA labelling patterns of the developing Sertoli cells are described in reference to events in the seminiferous epithelium.

* Present address: Department of Anatomy, The Albany Medical College of Union University, Albany, New York, U.S.A. 


\section{MATERIALS AND METHODS}

\section{General procedures}

Sprague-Dawley rats were used in all experiments. Weanling and adult animals were maintained at $25^{\circ} \mathrm{C}$ and allowed free access to a diet of Purina rat chow and water in animal quarters having a 12-hr light-dark cycle. Young were weaned at 21 days of age.

Testis tissue was fixed in Bouin's fluid for 12 to $18 \mathrm{hr}$ before dehydration and embedding in paraffin wax. Sections ( $5 \mu \mathrm{m}$ thick) were mounted on slides, dehydrated in alcohol, air-dried and coated with Kodak NTB-2 liquid emulsion for autoradiography. Slides were stored at room temperature in black bakelite boxes for the duration of the exposure period. Subsequently, the autoradiograms were developed in Kodak D-19 developer, washed, fixed in Kodak fixer, stained with Harris' haematoxylin and chromotrope $2 \mathrm{R}$ and mounted for examination.

In all experiments, the radioisotopes were injected intraperitoneally. All injections were made at 10.00 hours to minimize the possibility of fluctuations in mitotic activity which might have resulted from diurnal rhythms. Tritiated thymidine (New England Nuclear Corp., Boston, Mass.) with a specific activity of $2 \cdot 0 \mathrm{Ci} / \mathrm{mmol}$ was used in all experiments.

\section{Tritiated thymidine studies}

Various parameters of the generation cycle were determined for the supporting cells of the newborn rat testis. Animals were injected on the day of birth with $\left[{ }^{3} \mathrm{H}\right]$ thymidine in a dosage of $0.5 \mu \mathrm{Ci} / \mathrm{g}$ body weight. Three rats were killed at each of thirty-six consecutive hourly intervals following the administration of the isotope. Autoradiograms were prepared and subsequently exposed for 2 weeks before development. The percentage of labelled metaphase figures was plotted versus time following injection and estimates of various phases of the generation cycle were made from the curve.

To determine the percentage of supporting cells labelled with $\left[{ }^{3} \mathrm{H}\right]$ thymidine as a function of age, rats in groups of three were injected with the isotope and killed $1 \mathrm{hr}$ after the injection on Day 1 and then at weekly intervals for 8 weeks after birth. Autoradiograms were prepared and allowed to expose for 2 weeks before development. Mitotic indices (number of mitotic figures/total number of supporting cells scored) were determined for animals up to 14 days of age in the same preparations used for the computation of the percentage of labelled cells, as well as in preparations from control animals which had received no radioisotopes.

\section{RESULTS}

\section{Generation cycle parameters}

From the plot of the percentage of labelled metaphase figures versus time after injection (Text-fig. 1), the mean duration of DNA synthesis (S) was estimated to be $10 \cdot 1 \mathrm{hr}$. Using the method of Wimber (1963), this value was derived by measuring the distance between the ascending and descending portions of the curve at the $50 \%$ point on the ordinate. The slopes of the 
ascending and descending limbs were calculated by means of the inverse sine transformation and found to be $12 \cdot 6$ and $-16 \cdot 6$, respectively.

After a pulse exposure to $\left[{ }^{3} \mathrm{H}\right]$ thymidine, it is ordinarily possible to observe two successive waves of labelled mitotic figures. The measurement of the generation cycle time $\left(T_{c}\right)$ is usually made between the midpoints of the peaks of the two successive waves. The interval between corresponding points on the ascending limbs of the two successive waves is also considered a measure of the

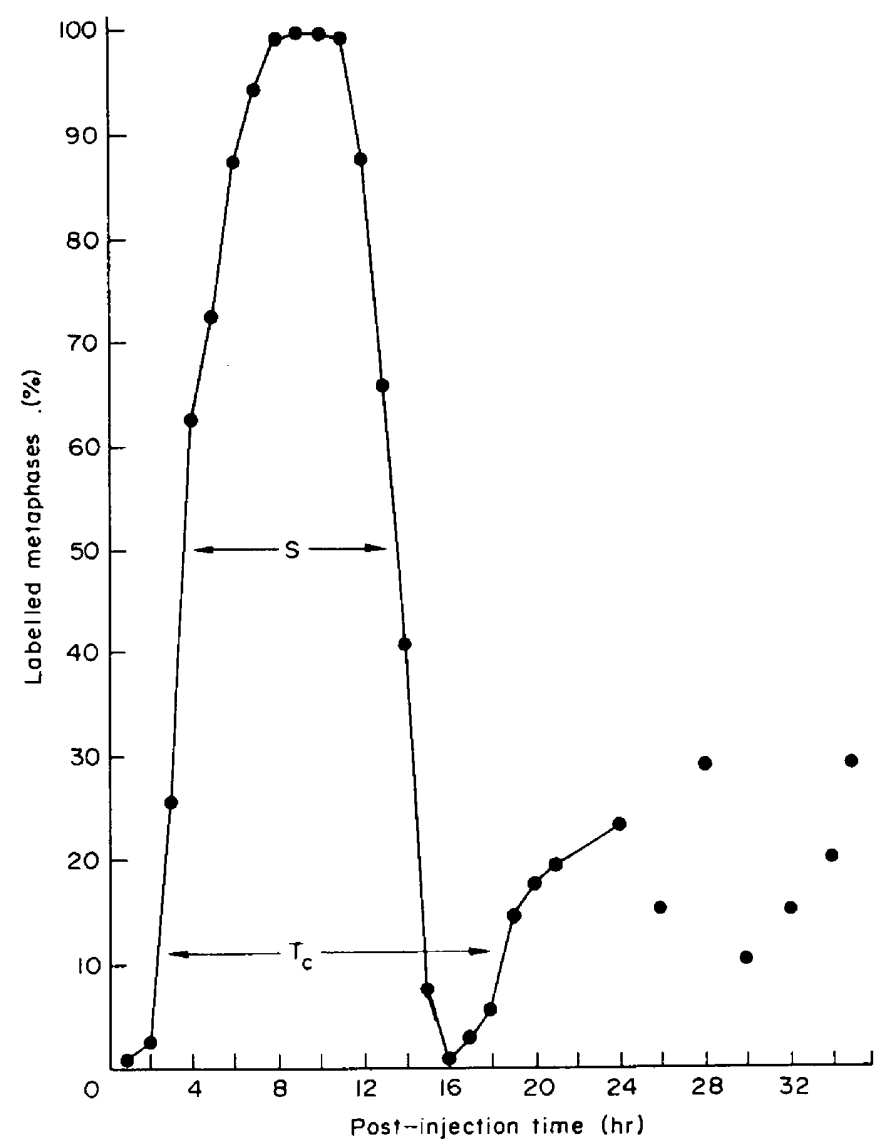

TEXT-FIG. 1. Curve showing the percentage of labelled metaphase figures seen in the supporting cells of the newborn rat testis over a period of $36 \mathrm{hr}$ following a single injection of $\left[{ }^{3} \mathbf{H}\right]$ thymidine. Intervals corresponding to DNA synthesis $(\mathbf{S})$ and the generation cycle time $\left(T_{c}\right)$ are indicated on the curve. Each point on the curve represents the mean value obtained from at least 750 metaphase figures scored.

generation cycle time (Baserga \& Weibel, 1969). In the present experiment, a complete second wave of labelled mitoses was not obtained, although a portion of the ascending slope of the second wave was present. Consequently, the mean generation cycle time was estimated from the distance between corresponding points on the successive ascending slopes to be about $16.4 \mathrm{hr}$.

The duration of mitosis $(\mathbf{M})$ was computed as the product of the generation cycle time and the mitotic index (Quastler, 1963). In the present study, the 
mean mitotic index computed over the duration of the generation cycle was 0.046 . If this number is multiplied by the generation time of $16.4 \mathrm{hr}$, a mitotic time of $0.75 \mathrm{hr}$ is obtained.

From the curve in Text-fig. 1, it is possible to estimate the minimum duration of $\mathrm{G}_{2}+\mathrm{P}$ (post-DNA synthesis time plus prophase) as well as the mean duration of this interval. The appearance of the first labelled metaphase figures at $2 \mathrm{hr}$ after injection represents the minimum duration of the $G_{2}+P$ phase of the cell cycle. The mean duration of this phase is estimated to be $3.6 \mathrm{hr}$, an interval corresponding to the span from 0 time to the time at which $50 \%$ of the metaphase figures are labelled. The mean duration of $\mathrm{G}_{2}$ alone is, therefore, somewhat less than $3.6 \mathrm{hr}$.

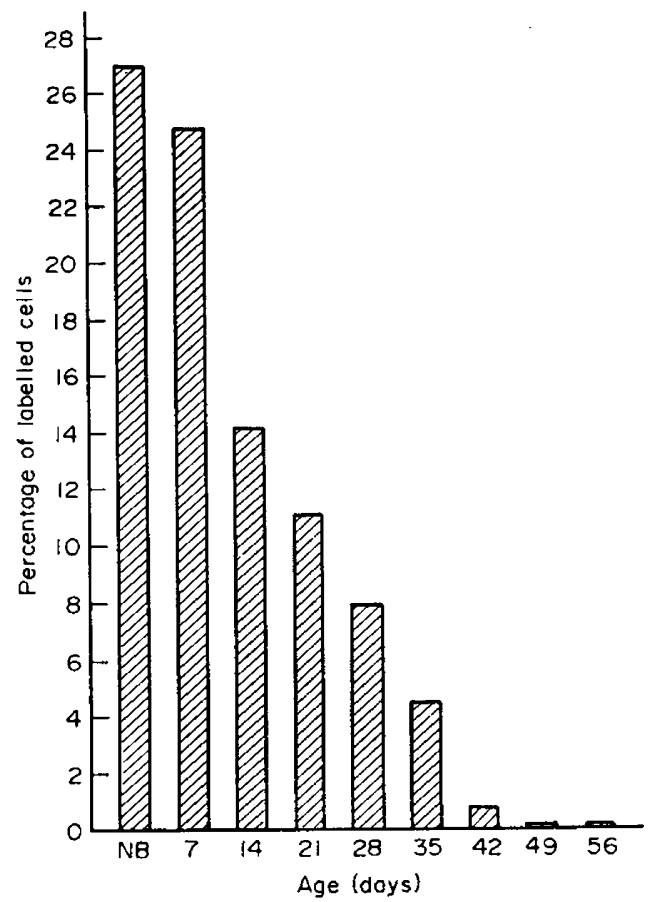

TEXT-FIG. 2. Graph illustrating the change in the percentage of labelled supporting cells (Sertoli cells in older animals) with respect to age. All rats were killed $1 \mathrm{hr}$ after the injection of $\left[{ }^{3} \mathrm{H}\right]$ thymidine.

Knowing the generation time, the duration of DNA synthesis and the percentage of interphase cells labelled over the duration of the entire cell cycle, one can compute the growth fraction (proliferating pool) of the cells in question. The percentage of interphase labelling was determined to be $31 \cdot 8$. According to Post \& Hoffman (1964), the proliferating pool

$$
=\frac{\text { generation time } \times \% \text { interphase labelling }}{\text { DNA synthesis time }}
$$

This formula yields a proliferating pool of $52 \%$ or a growth fraction of 0.52 for the present experiment. 
Mitotic and labelling patterns

The data illustrated in Text-fig. 2 indicate that there is a continual decrease in the percentage of labelled supporting cells until about 7 weeks after birth. At this time, virtually none of the Sertoli cells shows any incorporation. It is noteworthy that, by 7 weeks after birth, the first wave of spermatozoa has matured and the Sertoli cells are fully differentiated. The most marked decrease in labelling occurred 2 weeks after birth, which is about the same time that virtually all of the mitotic activity in the supporting cells ceases (Text-fig. 3). By this time, spermatogenesis has reached early meiotic prophase. It should be pointed out that the mitotic index of 0.032 for newborn animals represented in Text-fig. 3 differs from the value of 0.046 used in the computation of the

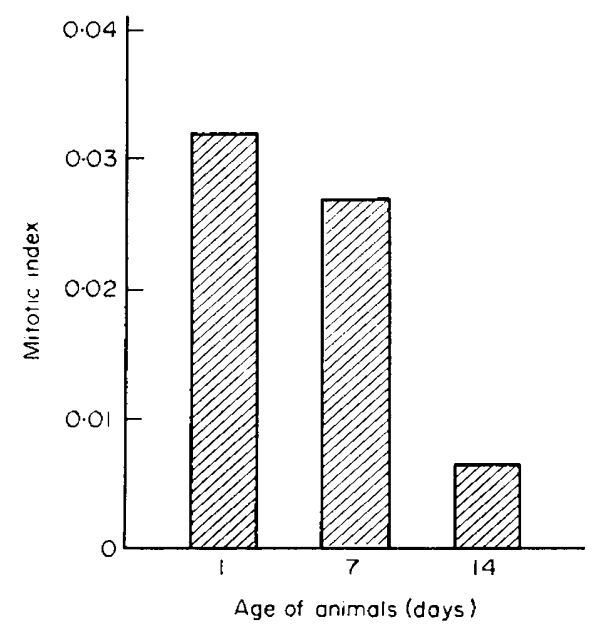

TeXT-FIG. 3. Graph illustrating the change in the mitotic index with respect to the age of the supporting cells of the rat testis.

duration of mitosis. The reason is that the latter index was determined over the duration of the generation cycle and represents a mean value for the entire $16 \mathrm{hr}$, whereas the value represented in Text-fig. 3 was obtained at only one time interval to correspond with the time at which the labelling index was determined. The mitotic indices obtained from animals which had received $\left[{ }^{3} \mathrm{H}\right]$ thymidine were not significantly different from those obtained in animals which had received no isotope at all, indicating that the tritium in the dosage used here had no effect on the mitotic activity.

\section{DISCUSSION}

The cell cycle curve obtained in the present work differs from most in that a second wave of labelled mitoses was not observed. A similar phenomenon was also reported by Fabrikant (1967) for the cells of regenerating rat liver. The labelled cohort of supporting cells divided in synchrony for one complete division cycle and the beginning of the second. At some time during the second wave of mitotic activity, division became asynchronous. Fabrikant (1967) suggested that the absence of a second wave of labelled mitoses might be the result 
of a spread in the duration of the interval following mitosis and before DNA synthesis, with the subsequent loss of phase coherence of the labelled population.

The duration of DNA synthesis observed in the present work is about half that reported by Hilscher \& Makoski (1968) for rat supporting cells. Although the same cell types were examined in both studies, different strains of rats were used. This may account for some variation in the data. The estimation of the duration of $\mathrm{S}$ was made in the same manner in both reports.

An indication of the degree of variability in the duration of DNA synthesis can be obtained from an analysis of the shape of the curve for the percentage of labelled metaphases. If the slopes of the ascending and descending limbs are symmetrical, there is little or no variability in S. Conversely, if the limbs give rise to an asymmetrical curve, there must be variation in the duration of $S$ among individual cells in the population (Gleaver, 1967). Using the inverse sine transformation (Monesi, 1962), the slopes were found to be 12.6 and $-16 \cdot 6$, indicating some variability in the duration of $S$ among the supporting cells of the newborn rat testis.

Hilscher \& Makoski (1968) concluded that the growth of the supporting cells was exponential and on this basis computed a generation time of $38 \mathrm{hr}$. The present estimation of the mean generation time was made directly from the curve of the percentage of labelled metaphases and found to be $16 \cdot 4 \mathrm{hr}$. The use of the latter method was based on the finding that the growth fraction of the supporting cells is about $0 \cdot 52$. To use the formula employed by Hilscher \& Makoski, the growth fraction must be equal to 1.00 with all cells involved in active proliferation. Such does not seem to be true in the present work and Baserga \& Weibel (1969) state that very few mammalian tissues have a growth fraction of 1 , or even approaching 1 .

It is apparent from the present findings and those of Clermont \& Perey (1957) that the majority of mitotic activity of the supporting cells of the rat ceases about 2 weeks after birth. If mitosis occurs at all after this time, it is minimal and cannot be determined with any accuracy. Thus, there is a simultaneous cessation of the mitotic activity in the supporting cells and a quickening in the meiotic activity of the germinal cells.

It has been reported by Courot (1967) that the number of supporting cells in the testis of the impuberal lamb increases between the time of birth and the beginning of spermatogenic activity. The mitotic activity of these cells, which continues until spermatogenic activity begins, allows the accumulation of important reserves of supporting cells before the onset of spermatogenesis (Courot, 1967). The observations of the present work corroborate these findings in the rat, since the most dramatic decrease occurs in both the percentage of labelled cells and the percentage of cells in mitosis very shortly after spermatogenic activity has begun.

Clermont \& Perey (1957) concluded that by 15 days after birth the number of supporting cells and also the number of Sertoli cells into which they later transformed seemed to be fixed for the remainder of the life of the rat. If the $\left[{ }^{3} \mathrm{H}\right]$ thymidine labelling indices of the supporting cells are examined at various intervals after birth, an alternative to this conclusion occurs. The supporting cells continue to incorporate $\left[{ }^{3} \mathrm{H}\right]$ thymidine until about 7 weeks after birth. 
In most instances, observations have been compatible with the assumption that incorporation of the precursor into DNA represented synthesis in preparation for cell division (Pelc, 1963). Based on this assumption, the supporting cells continue their division processes much longer than their mitotic indices indicate, with mitotic activity falling to 0 by the time the supporting cells become mature Sertoli cells. This is compatible with the belief that mature Sertoli cells do not divide in vivo (Clegg, 1963).

On the other hand, Pelc (1963) presented evidence that in many tissues DNA is not perfectly stable. Incorporation of the precursor at the full rate does not always lead to mitosis and incorporation at a low rate is unlikely to be sufficient for the synthesis of $2 \mathrm{C}$ amounts of DNA. Pelc stated that the synthesis of DNA in limited quantities could be used for the occasional replenishment of faulty DNA or to fill some local need when extra amounts of DNA are required. In the light of this information, it is conceivable that, while most of the mitotic activity of the supporting cells may cease 2 weeks after birth, some cells may continue to incorporate $\left[{ }^{3} \mathrm{H}\right]$ thymidine without subsequent cell division until about 7 weeks after birth. It would be of interest to know for what purpose this extra DNA might be synthesized.

\section{ACKNOWLEDGMENT}

Supported by Training Grant No. 5-TI-GH-326 from the National Institutes of Health.

\section{REFERENGES}

Baserga, R. \& Weibel, F. (1969) The cell cycle of mammalian cells. Int. Rev. exp. Path. 7, 1. GleAver, J. E. (1967) Thymidine metabolism and cell kinetics, p. 115. John Wiley, New York.

CLEGG, E. J. (1963) Studies on artificial cryptorchidism: morphological and quantitative changes in the Sertoli cells of the rat testis. F. Endocr. 26, 567.

Glermont, Y. \& Perey, B. (1957) Quantitative study of the cell population of the seminiferous tubules in immature rats. Am. 7. Anat. 100, 241.

Courot, M. (1967) Endocrine control of the supporting and germ cells of the impuberal testis. $\mathcal{F}$. Reprod. Fert. Suppl. 2, 89.

Fabrikant, J. I. (1967) The effect of prior continuous irradiation of the $G_{2}, M$, and $S$ phases of proliferating parenchymal cells in the regenerating liver. Radiat. Res. 31, 304.

Fitckinger, G. J. (1967) The postnatal development of the Sertoli cells of the mouse. Z. Zellforsch. mikrosk. Anat. 78, 92.

Gardner, P. J. \& Holyoke, E. A. (1964) Fine structure of the seminiferous tubule of the Swiss mouse. I. The limiting membrane, Sertoli cells, spermatogonia, and spermatocytes. Anat. Rec. 150, 391.

HILscher, W. \& MAKOsKI, H. B. (1968) Histologische und autoradiographische Untersuchungen zur "Präspermatogenese" und "Spermatogenese" der Ratte. Z. Zellforsch. mikrosk. Anat. 86, 327.

MONSEI, V. (1962) Autoradiographic study of DNA synthesis and the cell cycle in spermatogonia and spermatocytes of mouse testis using tritiated thymidine. 7. Cell Biol. 14, 1.

PeLc, S. R. (1963) Incorporation of labelled precursors of DNA in non-dividing cells. In: Cell Proliferation, pp. 94-109. Eds. L. F. Lamerton and R. J. M. Fry. Blackwell Scientific Publications, Oxford.

Post, J. \& Hoffman, J. (1964) Changes in the replication times and patterns of the liver cell during the life cycle of the rat. Expl Cell Res. 36, 111.

QuastreR, H. (1963) The analysis of cell proliferation kinetics. In: Cell Proliferation, p. 25. Eds. L. F. Lamerton and R. J. M. Fry. Blackwell Scientific Publications, Oxford.

SAPSFord, G. S. (1962) Changes in the cells of the sex cords and the seminiferous tubules during the development of the testis of the rat and mouse. Aust. F. Zool. 10, 178.

SAPsford, C. S. (1963) The development of the Sertoli cell of the rat and mouse: its existence as a mononucleate unit. F. Anat. 97, 225.

Wimber, D. E. (1963) Methods for studying cell proliferation with emphasis on DNA labels. In: Cell Proliferation, p. 9. Eds. L. F. Lamerton and R. J. M. Fry. Blackwell Scientific Publications, Oxford. 